\title{
COMMENTARY
}

\section{Obesity and the brain: a possible genetic link}

\author{
Lars Bertram* and Hauke Heekeren ${ }^{2,3}$
}

\begin{abstract}
Structural brain deficits have been repeatedly linked to body mass index and obesity, which itself is controlled by the effects of a number of independent genetic loci. One of the most consistently replicated of these putative obesity genes is fat mass and obesity-associated protein (FTO). A recent study by investigators from the Alzheimer's Disease Neuroimaging Initiative set out to assess whether polymorphisms in FTO are directly correlated with brain volume in a collection of over 200 healthy older individuals. The authors found a modest but significant reduction in brain volume in the frontal and occipital lobes exerted by the same FTO alleles that also predispose to obesity. Although potentially providing a novel genetic link between obesity and brain structure, the relevance of these findings for normal brain function and disease remains to be determined.
\end{abstract}

Genes play a crucial role in controlling phenotypic variability of essentially all aspects of life, including susceptibility to disease. A better understanding of the genetic factors affecting the development and function of the central nervous system, especially the human brain, are of particular interest owing to the increasing prevalence of neurodegenerative disorders such as Alzheimer's disease (AD).

Investigators from the Alzheimer's Disease Neuroimaging Initiative (ADNI) - a research project aimed at studying the rate of change of cognition, brain structure and function, and biomarkers in large collections of both cognitively healthy and impaired subjects - recently published data suggesting a possible connection between certain common genetic variants and brain volume in $\sim 200$ healthy older subjects [1]. Specifically, the authors tested the hypothesis of whether or not specific alleles in

\footnotetext{
*Correspondence: Ibertram@molgen.mpg.de

'Neuropsychiatric Genetics Group, Max-Planck Institute for Molecular Genetics,

Ihnestrasse 63, Room 204.1, 14195 Berlin, Germany

Full list of author information is available at the end of the article
}

the gene encoding the fat mass and obesity-associated protein $(F T O)$, located on chromosome 16q12.2, correlate with regional brain volumes as determined by magnetic resonance imaging.

This question arose because the same FTO alleles at highly correlated - SNPs were previously found to show association with elevated body mass index (BMI), a commonly used surrogate measure of adiposity [2-5]. Elevated BMI itself has been reported to correlate with structural brain deficits - in particular, frontal, temporal, and subcortical atrophy [6] - but no study had previously assessed whether this correlation was driven by genetic variation in the $F T O$ gene.

The new data from the ADNI group show that, indeed, the same common SNPs associated with BMI are also associated with a $\sim 10 \%$ reduction in brain volume in the frontal and occipital lobes, while elevated BMI alone was associated with relatively broadly distributed brain atrophy in the frontal, temporal, parietal and occipital lobes [1]. As expected, the FTO association was highly correlated with the overall effect of BMI on brain volume, but the investigated FTO variants appeared to exert a small, but detectable, effect over and above what is explained by BMI alone. Interestingly, the FTO-related decrease in brain volume was not attributable to structural effects of microvascular damage in the white matter, as different regions of the brain were affected by both variables.

From the currently available data, it is impossible to judge which of the associated FTO sequence variants might confer the molecular effects underlying these genetic findings. The chromosomal region spanning the FTO gene is characterized by high inter-marker correlation (that is, linkage disequilibrium), making it difficult to determine which SNP is mainly driving the association. Interestingly, however, several of the polymorphisms determined either directly or indirectly by the ADNI group (that is, rs17817449, rs3751812 and rs1421085) were shown in a recent study to map to putative in silico functional elements [5] - although these observations still have to be confirmed in vitro. It has been previously suggested that, on a biochemical level, multiple processes could plausibly explain the role of FTO protein in weight regulation and obesity; for example, by controlling feeding behavior (possibly via 
neuronal circuits governing appetite) and/or energy expenditure (reviewed in [7]). Whether or not these same mechanisms are relevant for the potential effects of FTO on brain structure remains currently unclear.

As with any genetic association finding, the new results outlined above have some limitations and their potential relevance on brain function and dysfunction currently remains elusive. First, the investigated ADNI cohort was relatively small $(n=206)$, which increases the chance of sampling error and other biases, possibly leading to artifactual results. Small sample size also decreases power, which at least partially explains the rather modest degree of statistical support for most of the reported FTO findings. For instance, the study could not entirely exclude the possibility that the observed association between FTO and structural brain changes was merely a result of confounding with the - much more pronounced BMI effects on brain volume, or a bona fide independent signal. Replication analyses in sufficiently powered and independent datasets will help to resolve this issue.

Second, FTO is not the only gene associated with BMI and obesity in humans. Several other loci - such as MC4R, NPC1, MAF, and PTER - have recently been identified to also play significant roles [8]. Assessing whether these genes also exert specific effects on brain structure would therefore be of interest. Conversely, it would be interesting to see whether other genes not related to obesity and BMI possibly show an even more pronounced association with brain atrophy than $F T O$; for example, after genome-wide screening.

Third, it will be interesting to see whether and how the reduction in brain volume in the frontal and occipital lobes exerted by FTO translates into altered cerebral function (for example, as measured using functional magnetic resonance imaging), and/or behavior in healthy subjects.

Finally, whether or not the reported FTO-brain connection has any relevance to neurodegenerative conditions, such as AD, remains to be seen. Only healthy older subjects have thus far been investigated, and the brain regions possibly affected by FTO (that is, the frontal and occipital lobes) are not typically struck early in the course of $\mathrm{AD}$. A related study from the same ADNI investigators recently reported an association between elevated BMI and lower brain volume in subjects suffering from $\mathrm{AD}$ and mild cognitive impairment [9], although no results were reported on whether these effects were also correlated with FTO genotype. Furthermore, no study - including the several published genome-wide association studies [10] - has yet reported evidence for significant association between polymorphisms in FTO and $\mathrm{AD}$ risk or related phenotypes [11]. Based on the most recent ADNI data, however, this would seem a logical and promising hypothesis to test next.
In summary, the new ADNI data provide the first evidence for a possible link between one of the most important obesity genes and brain structure. Additional investigations are necessary to corroborate these findings, and to determine their relevance for normal brain function and disease.

\section{Abbreviations}

AD, Alzheimer's disease; ADNI, Alzheimer's Disease Neuroimaging Initiative; BMI, body mass index; FTO, fat mass and obesity-associated protein; SNP, single nucleotide polymorphism.

\section{Competing interests}

The authors declare that they have no competing interests.

\section{Author details}

'Neuropsychiatric Genetics Group, Max-Planck Institute for Molecular Genetics, Ihnestrasse 63, Room 204.1, 14195 Berlin, Germany. ${ }^{2}$ Max Planck Institute for Human Development, Lentzeallee 94, 14195 Berlin, Germany. ${ }^{3}$ Department of Education and Psychology, Freie Universität Berlin, Habelschwerdter Allee 45, 14195 Berlin, Germany.

\section{Published: 27 September 2010}

\section{References}

1. Ho AJ, Stein JL, Hua X, Lee S, Hibar DP, Leow AD, Dinov ID, Toga AW, Saykin AJ, Shen L, Foroud T, Pankratz N, Huentelman MJ, Craig DW, Gerber JD, Allen AN, Corneveaux JJ, Stephan DA, DeCarli CS, DeChairo BM, Potkin SG, Jack CR, Jr, Weiner MW, Raji CA, Lopez OL, Becker JT, Carmichael OT, Thompson PM: A commonly carried allele of the obesity-related FTO gene is associated with reduced brain volume in the healthy elderly. Proc Natl Acad SciU S A 2010, 107:8404-8409.

2. Scuteri A, Sanna S, Chen WM, Uda M, Albai G, Strait J, Najjar S, Nagaraja R, Orru M, Usala G, Dei M, Lai S, Maschio A, Busonero F, Mulas A, Ehret GB, Fink AA, Weder AB, Cooper RS, Galan P, Chakravarti A, Schlessinger D, Cao A, Lakatta E, Abecasis GR: Genome-wide association scan shows genetic variants in the FTO gene are associated with obesity-related traits. PLOS Genet 2007, 3:e115.

3. Scott $\sqcup$, Mohlke KL, Bonnycastle LL, Willer CJ, Li Y, Duren WL, Erdos MR, Stringham HM, Chines PS, Jackson AU, Prokunina-Olsson L, Ding CJ, Swift AJ, Narisu N, Hu T, Pruim R, Xiao R, Li XY, Conneely KN, Riebow NL, Sprau AG, Tong M, White PP, Hetrick KN, Barnhart MW, Bark CW, Goldstein JL, Watkins L, Xiang F, Saramies J, et al: A genome-wide association study of type 2 diabetes in Finns detects multiple susceptibility variants. Science 2007, 316:1341-1345.

4. Frayling TM, Timpson NJ, Weedon MN, Zeggini E, Freathy RM, Lindgren CM, Perry JR, Elliott KS, Lango H, Rayner NW, Shields B, Harries LW, Barrett JC, Ellard S, Groves CJ, Knight B, Patch AM, Ness AR, Ebrahim S, Lawlor DA, Ring SM, Ben-Shlomo Y, Jarvelin MR, Sovio U, Bennett AJ, Melzer D, Ferrucci L, Loos RJ, Barroso I, Wareham NJ, et al: A common variant in the FTO gene is associated with body mass index and predisposes to childhood and adult obesity. Science 2007, 316:889-894.

5. Dina C, Meyre D, Gallina S, Durand E, Korner A, Jacobson P, Carlsson LM, Kiess W, Vatin V, Lecoeur C, Delplanque J, Vaillant E, Pattou F, Ruiz J, Weill J, LevyMarchal C, Horber F, Potoczna N, Hercberg S, Le Stunff C, Bougneres P, Kovacs P, Marre M, Balkau B, Cauchi S, Chevre JC, Froguel P: Variation in FTO contributes to childhood obesity and severe adult obesity. Nat Genet 2007, 39:724-726.

6. Taki Y, Kinomura S, Sato K, Inoue K, Goto R, Okada K, Uchida S, Kawashima R, Fukuda $\mathrm{H}$ : Relationship between body mass index and gray matter volume in 1,428 healthy individuals. Obesity (Silver Spring) 2008, 16:1 19-124.

7. Fawcett KA, Barroso I: The genetics of obesity: FTO leads the way. Trends Genet 2010, 26:266-274.

8. Meyre D, Delplanque J, Chevre JC, Lecoeur C, Lobbens S, Gallina S, Durand E, Vatin V, Degraeve F, Proenca C, Gaget S, Korner A, Kovacs P, Kiess W, Tichet J, Marre M, Hartikainen AL, Horber F, Potoczna N, Hercberg S, Levy-Marchal C, Pattou F, Heude B, Tauber M, McCarthy MI, Blakemore Al, Montpetit A, Polychronakos C, Weill J, Coin LJ, et al: Genome-wide association study for early-onset and morbid adult obesity identifies three new risk loci in European populations. Nat Genet 2009, 41:157-159. 
9. Ho AJ, Raji CA, Becker JT, Lopez OL, Kuller LH, Hua X, Lee S, Hibar D, Dinov ID, Stein JL, Jack CR, Jr, Weiner MW, Toga AW, Thompson PM: Obesity is linked with lower brain volume in $700 \mathrm{AD}$ and $\mathrm{MCl}$ patients. Neurobio/ Aging 2010, 31:1326-1339.

10. Bertram L, Tanzi RE: Genome-wide association studies in Alzheimer's disease. Hum Mol Genet 2009, 18:R137-R145.

11. Bertram L, McQueen MB, Mullin K, Blacker D, Tanzi RE: Systematic meta-analyses of Alzheimer disease genetic association studies: the AlzGene database. Nat Genet 2007, 39:17-23.

doi:10.1186/alzrt51

Cite this article as: Bertram $\mathrm{L}$, Heekeren $\mathrm{H}$ : Obesity and the brain: a possible

genetic link. Alzheimer's Research \& Therapy 2010, 2:27. 